\title{
ASSESSMENT OF THE QUALITY MANAGEMENT SYSTEM IN WOODWORKING COMPANIES
}

\author{
Arta Rozentale ${ }^{1}$, Inta Kotane ${ }^{2}$ \\ ${ }^{1}$ Student at Master of EKSI, Rezekne Academy of Technologies, Rezekne, Latvia, \\ e-mail: rozentale.arta@gmail.com \\ ${ }^{2}$ Mg.oec., lecturer, researcher, Rezekne Academy of Technologies, Rezekne, Latvia, \\ e-mail: inta.kotane@rta.lv
}

\begin{abstract}
The woodworking industry, with its universal and wide use of products and the level of employment of people, has existed for centuries and will continue to do so, as forest management and the processing of harvested timber is a long process. Customizing consumer orders ranging from cheap everyday things to exclusive, individual projects is about quality. And for quality assurance, companies in various industries have developed and use a general quality management system standard - ISO 9001. The topicality of the research relates to the companies' doubts about the implementation and maintenance of the quality management system (ISO 9001) as a valuable long-term investment in the company's development and market expansion. The aim of the research is to study the quality management system of three wood processing companies and to evaluate them.

In the research, the authors gave insight into the development of the concept of quality and the formation of the quality management system, the ISO 9001 quality standard. The assessment of the quality management system of three wood processing companies is based on the main financial performance indicators of the companies.
\end{abstract}

Keywords: quality management system, wood processing, ISO 9001 standard. JEL code: L150.

Received: 27 May 2020 / Revised: 3 June 2021 / Accepted:17 September 2021

Published: 30 November 2021

\section{Introduction}

Quality is a relative concept that is associated with different explanations for different people. The word 'quality' is most often understood to mean each material product, software, material and service that can be assessed using characteristics that are often quite different for each type of product. Quality is a set of characteristics of an object that determines its compliance with certain or imagined requirements (Kvalitātes vadīšana, 1999, pp. 5). Over time, a common quality management system standard, ISO 9001 has developed and is being used to enable consumers to rely on a manufacturer or service provider. It is known all over the world and confirms the company's compliance with its requirements. A quality management system - organizational, financial and technical management, concerted action, activities, processes and means for the implementation of 
quality, safety, security and environmental compatibility, efficient and effective quality management (Kvalitātes vadīšana, 1999, pp. 5).

There are many researches and scientific research papers about quality management systems, the systems' impacts on different organizations, companies - local and international: D. Handke and D. Edelhoff (2016), B. Başaran (2016), T. Kravchenko and I. Saienko (2020) etc.

The present research used the quality management system ISO 9001 "Quality Management Systems. Requirements (ISO 9001: 2015)". The standard defines a quality management system model (Kvalitātes pārvaldības sistēmas. Prasības (ISO 9001:2015), 2017) applicable to both organizations and companies. The quality management system is based on the ISO 9000 standard set.

A set of quality can be expressed in terms of quality levels: product quality, operational quality, company quality and overall quality (Байда, 2016, pp. 2).

The ISO 9001 quality management standard is by far the most common quality management system framework used by organizations in more than 170 countries around the world. It sets the standard not only for quality management systems but also for management systems in general (ISO 9001 , s.a.). More than a million organizations around the world have underwent ISO 9001 certification, one of the world's most widely used management tools.

The first quality management system in Latvia was certified at the end of 1995. With Latvia's involvement in the European Union (EU) competition area, the popularity of the quality management system and the development of the conformity of production system and its accreditation in accordance with the requirements of the ISO standard increased (Drinke, 2019, pp. 245). Only in the last ten years in Latvia, the quality management system has started to become more relevant and in demand; in 2008 there were 500 certified companies, but in 2018 - 962 certified companies in Latvia (ISO Survey of certifications to management system standards, 2020).

In 2018 in Latvia, forests totalled 3.4 million hectares and covered 52\% of the country's area (Meža nozare skaițos un faktos: 2018, 2019); therefore, the forest is called Latvia's "green gold". Today, the forest sector is one of the main cornerstones of the national economy. The share of forestry, wood processing and furniture production in the gross domestic product in 2019 was $5.1 \%$, while the volume of exports reached EUR 2.6 billion - $20 \%$ of the country's total exports. There is no parish in Latvia where one could not find a smaller or larger wood processing company. They are often the most important employers in rural areas, and therefore the mainstay of the local economy and population (Meža nozare skaiț̣os un faktos: 2021, 2020; Meža nozare cilvēkam, s.a.). 
The quality management system means continuous development and improvement of the company, therefore more and more companies choose to integrate the basic principles of the quality management system into the company's operations. Some of these companies also undergo certification to provide their customers and partners with a certificate of compliance with this system.

The research aim relates to a company's doubts about the quality management system - ISO 9001, its implementation and maintenance as a valuable long-term investment in the company's development and market expansion.

The research examines quality management systems in real companies operating in the field of wood processing. The companies are limited liability companies and correspond to medium-sized companies in Latvia.

Object of research: quality management system.

Research subject: quality management system costs.

The aim of the research is to analyse and evaluate the quality management systems in wood processing companies and to develop proposals for their improvement.

To achieve the aim of the research, the authors set the following research tasks:

1. Analyse quality management systems or their absence in the wood processing companies involved in the research study.

2. Evaluate the impact of the quality management system on the financial performance of the companies researched.

3. Develop conclusions and make proposals.

Hypothesis of the research: the implementation of the quality management system in the company promotes the increase of the company's quality by streamlining the company's processes, and has a positive effect on the company's financial performance.

The research uses general scientific research methods: the monographic and descriptive methods and the comparative analysis method, data grouping, and the graphical method.

Research period - the years 2017-2019 for analysing the financial performance indicators of companies related to the quality management system.

\section{Quality management system review in companies}

The quality management system requires investment from the company and at the same time helps the company to increase profit (revenue). In business, it is important to identify not only the criteria for determining quality but also the potential maintenance costs. A number of proposals have 
been made in the industry, notably the recommendation by P.B. Crosby (Philip Bayard "Phil" Crosby) that the cost of a quality management project should not exceed $2.5 \%$ of total expenditure. Other authors believe that up to $15 \%$ of the funds obtained from sales should be used for quality assurance and should include such expenses as repair of defects, production material stocks, re-maintenance, quality control, provision of guarantees (Forands, 2009, pp. 215).

"Company 1" - a limited liability company, founded in 1993. "Company 1" Ltd. has three main areas of activity - production of wooden windows and doors, production of wood pellets, production of sawn timber and glued material. "Company 1" Ltd. introduced the quality management system in 2009 (Intervija ar SIA “Uzñēmums 1" izpilddirektoru S. K., 2020). The initial team that maintained the quality management system consisted of three specialists - a quality manager, a technician and a laboratory technician (SIA "Uzṇēmums 1" iekšējie dokumenti (nepublicētie materiāli)).

In relation to the maintenance costs of the quality management system of "Company 1" Ltd., the company has set stricter limits, as indicated in the recommendations of P.B. Crosby (Forands, 2009, pp. 215). For "Company 1" Ltd., the costs of the quality management system do not exceed $1 \%$ of the total expenses. The company's internal quality goals also state that defective products (for which complaints are received from the customer) do not exceed on average $1 \%$ of the sold products, which have been successfully maintained so far. (SIA "Uzṇēmums 1" iekšējie dokumenti (nepublicētie materiāli)).

Quality management system maintenance costs 2017-2019. In 2017, quality management system costs which directly relate only to the maintenance of the ISO 9001 certificate, which includes staff wages, certification costs, training, departmental support and measuring instruments have decreased for "Company 1" Ltd. from EUR 77,500 (in 2017) to EUR 57.900 (in 2019). These are costs that are directly attributable to maintaining the ISO 9001 certificate and the corresponding quality management system, which are not small. During the research period, most of them - 93\% - were the remuneration of the employees of the quality department (see Table 1).

A comparison of the ratio of total cost of "Company 1" Ltd. to its costs attributable to ISO 9001 as a certificate not related to direct production control reveals that employee wages represent the highest percentage of total cost; in terms of total cost of the quality management system, the wages make up only $47 \%$, instead of $93 \%$ earlier. In terms of total cost, employee wages are followed by production sample costs and testing costs; if "Company 1" Ltd. works on the development of new products, additional product testing is also required, which increases its costs. 
An analysis of the experience of "Company 1" Ltd. and the distribution of its costs allows the authors to draw a conclusion that is consistent with the statement of other specialists mentioned above that the ISO 9001 certificate does not represent to the product quality, but to the overall quality of the company. ISO 9001 indicates the company's prestige and that the company has sufficient resources and a desire to maintain this certificate to attest to the high level of the company's quality management system.

Table 1. Total costs of the quality management system, euro, 2017-2019 (authors' construction based on the company's unpublished financial data)

\begin{tabular}{|l|c|c|c|c|c|c|c|c|c|}
\hline & \multicolumn{3}{|c|}{ “Company 1" Ltd. } & \multicolumn{3}{c|}{ “Company 2" Ltd. } & \multicolumn{3}{c|}{ “Company 3" Ltd. } \\
\cline { 2 - 12 } & 2017 & 2018 & 2019 & 2017 & 2018 & 2019 & 2017 & 2018 & 2019 \\
\hline Wages & 6000 & 5000 & 54000 & 2500 & 5000 & 30000 & 4500 & 4500 & 54000 \\
\hline Certification & 1800 & 2300 & 1800 & 1800 & 1800 & 1800 & 0 & 0 & 2300 \\
\hline Training & 1500 & 900 & 600 & 1500 & 600 & 800 & 0 & 0 & 0 \\
\hline $\begin{array}{l}\text { Departmental } \\
\text { supplies }\end{array}$ & 700 & 500 & 500 & 2000 & 2300 & 2000 & 500 & 1000 & 450 \\
\hline $\begin{array}{l}\text { Measuring } \\
\text { instruments }\end{array}$ & 1500 & 1000 & 1000 & 2000 & 2050 & 2000 & 1500 & 700 & 800 \\
\hline $\begin{array}{l}\text { Production } \\
\text { samples }\end{array}$ & 23000 & 60000 & 30000 & 75000 & 30000 & 35000 & 15000 & 10000 & 20000 \\
\hline Testing costs & 15000 & 40000 & 20000 & 55000 & 18000 & 20000 & 0 & 0 & 0 \\
\hline Other certificates & 10000 & 8000 & 6500 & 9000 & 7500 & 7000 & 7000 & 7000 & 7000 \\
\hline Total costs & $\mathbf{5 9 5 0 0}$ & $\mathbf{1 1 7 7 0 0}$ & $\mathbf{1 1 4 4 0 0}$ & $\mathbf{1 4 8 8 0 0}$ & $\mathbf{6 7 2 5 0}$ & $\mathbf{9 8 6 0 0}$ & $\mathbf{2 8 5 0 0}$ & $\mathbf{2 3 2 0 0}$ & $\mathbf{8 4 5 5 0}$ \\
\hline
\end{tabular}

“Company 2" - a limited liability company, founded in 2011. "Company 2" Ltd. is a young and fast-growing company, which, combining the experience of industry professionals and creating a strong team, has become one of the leading manufacturers of windows and doors in the Baltics. The factory is in modern premises, especially suitable for the production of wooden windows and doors.

Analysing the experience of "Company 2" Ltd. in implementing the quality management system and its maintenance, it should be taken into account that the company started operating relatively recently - in 2011 and developed rapidly; therefore, a full-fledged quality management system was introduced immediately with the establishment of the company. According to P.B. Crosby's recommendation, expenditure on the implementation of a quality management system should not exceed $2.5 \%$ of total expenditure (Forands, 2009, pp. 215); however, "Company 2" Ltd. does not limit its financial resources for the provision of a quality management system. It is important for the company that everyone in the company produces the highest quality product in Europe, as well as eliminates all customer 
problems that have arisen not only through the company's fault, because the company's priority is a satisfied customer.

The total maintenance cost of the quality management system (see Table 1) related to the maintenance of the ISO 9001 certificate has decreased during the reporting period from EUR 37,300 (2017) to EUR 36,600 (2019). Wage costs accounted for $80-90 \%$ of total cost.

An analysis of the highest costs and the costs attributable to ISO 9001 as a certificate not related to direct production control for "Company 2" Ltd. reveals that the wages of the employees represent the highest cost. Taking into account other costs, the employees' wages are in 2nd place, accounting for $30 \%$ of the total cost of the quality management system of Company 2 in 2019.

“Company 3" - a limited liability company, founded in 2012. "Company 3" Ltd. was established as a specialized large-scale, cost-effective contract manufacturer supplying branded residential and commercial playground equipment primarily for the European market (SIA "Uznēemums 3" pamatdati, 2020; SIA “Uzṇēmums 3" mājaslapa, 2020).

The economic activity of "Company 3" Ltd. is seasonal, and the highest level of production is reported from May to August. The products of "Company 3" Ltd. are mainly sold to one main customer $(70 \%$ of the production), which sells these products in the British market. A small part $30 \%$ - of the production is distributed among two other customers. The company does not offer to buy its products to local residents - neither individuals nor legal entities.

The quality management system of "Company 3" Ltd. started at the same time as the company was founded in 2012. Initially, one employee was responsible for the quality of the company's products and the maintenance of related certificates and documentation, who also performed other work duties. As the company develops, quality management measures have been performed by two employees since 2016 (SIA “Uzṇēmums 3" iekšējie dokumenti (nepublicētie materiāli)). For financial and strategic reasons, the company has not chosen to be certified for the ISO 9001 quality management system.

Identifying and evaluating the company's quality management systems in accordance with P.B. Crosby's recommendation reveals that expenditure on the implementation of a quality management system should not exceed $2.5 \%$ of total expenditure (Forands, 2009, p. 215). The costs directly attributable to the maintenance of the ISO 9001 certificate and the corresponding quality management system are not low. The majority - 94\% is made up of the remuneration of the quality department employees (see Table 1). 
Analysing the company's full quality management system and its costs for 2019, additional costs related to production samples and maintenance costs of other certificates should be taken into account. Production samples for quality control cost from EUR 15000 to EUR 20000 per year, maintenance costs for other certificates (including ISO 9001) per year - EUR 7000 (SIA “Uzñēmums 3" iekšējie dokumenti (nepublicētie materiāli)).

Although "Company 1" Ltd. and "Company 2" Ltd. adhere to different principles of quality management system development in terms of the number of employees and the technology of the manufactured products many employees and manual work are involved in the production of "Company 1" Ltd. products, while the main production of "Company 2" Ltd. involves the use of modern production equipment. The total costs of the quality management systems of both companies are relatively similar, the average costs of the quality management system and certifications, i.e. testing costs is EUR 137,533 for "Company 1" Ltd. and EUR 132,383 for "Company 2" Ltd. The costs are equal to the production sample and the amount of testing costs. The average quality management system cost of “Company 2" Ltd. was EUR 28,917 per year.

According to the authors, a calculation of the costs of a quality management system should take into account the amount of products and services complained of or the cost of remedying them, the cost of production incurred and the cost of reproduction. "Company 1" Ltd., unlike the other two companies, started listing and calculating the costs at the end of 2018, but it requires a lot of work in setting up and maintaining the system, so most often the companies calculate these costs approximately, calculating only the most significant costs for defects and complaints.

Analysing the costs of the quality management systems of all the companies examined, which directly relate to the maintenance of ISO 9001 certificates, the authors concluded that the situation was the same for all the companies - specialist wages made up 80-97\%, while the other related costs, such as certification costs, training, departmental support, measuring instruments accounted for only $1-5 \%$ of the total cost. In total, the costs were similar, on average EUR 66,700 for "Company 1" Ltd., EUR 46,883 for "Company 2" Ltd., EUR 56,333 for “Company 3" Ltd. The costs appear to be high, but compared with the total cost of a company's quality management system, where the costs of production samples, testing and other certificates have to be added, staff costs fall from $24 \%$ to $74 \%$. For "Company 1" Ltd., ISO 9001 certificate maintenance costs in the reporting period accounted for $48 \%$ of the total quality management system cost, for "Company 2" Ltd. the costs were only $35 \%$, while the highest cost were reported for "Company 3 " Ltd. at $72 \%$ of the total cost, because the company had no testing costs and very low production sample costs. In total in the reporting period, the highest 
quality management system costs were reported for "Company 1" Ltd., on average EUR 137.533, similar costs were reported for "Company 2" Ltd. at EUR 132.383, whereas the lowest costs were reported for "Company 3" Ltd. at EUR 78.416.

\section{Impact of the quality management system on the companies' financial performance}

The impact of a quality management system on a company's financial performance can be determined by analysing the company's key financial performance and the changes. The research analysed financial performance indicators for the companies (see Table 2), and the criteria of each company are highlighted in grey in the table, which were assessed as good and excellent.

Table 2. Financial performance indicators for "Company 1 " Ltd.,

"Company 2" Ltd. and “Company 3" Ltd., 2017-2019 (authors' construction based on the company's financial data, authors calculations)

\begin{tabular}{|c|c|c|c|c|c|c|c|}
\hline & 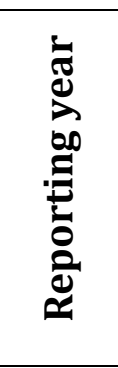 & 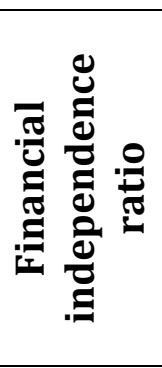 & o & 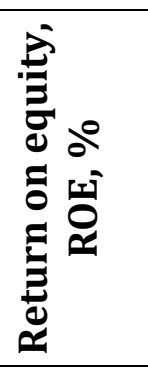 & 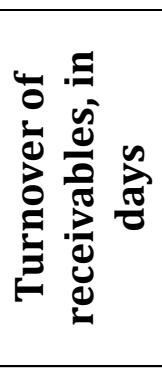 & 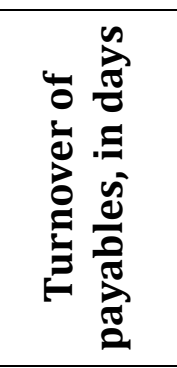 & 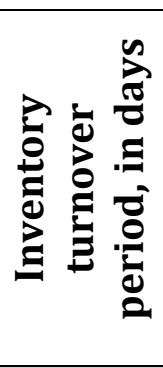 \\
\hline \multirow{3}{*}{$\begin{array}{c}\text { “Company 1" } \\
\text { Ltd. }\end{array}$} & 2017 & 0.46 & 1.56 & 3.39 & 18.85 & 140.21 & 85.01 \\
\hline & 2018 & 0.45 & 1.40 & 3.11 & 37.21 & 164.95 & 110.53 \\
\hline & 2019 & 0.53 & 5.94 & 11.28 & 35.90 & 133.19 & 109.23 \\
\hline \multirow{3}{*}{$\begin{array}{c}\text { “Company 3" } \\
\text { Ltd. }\end{array}$} & 2017 & -0.10 & -2.91 & -28.35 & 17.17 & 2085.02 & 0.00 \\
\hline & 2018 & 0.10 & 1.30 & 12.59 & 5.40 & 1062.12 & 0.00 \\
\hline & 2019 & 0.71 & 0.65 & 0.91 & 17.17 & 422.77 & 0.00 \\
\hline \multirow{3}{*}{$\begin{array}{c}\text { "Company 3" } \\
\text { Ltd." }\end{array}$} & 2017 & 0.37 & 17.81 & 48.66 & 4.20 & 37.00 & 31.67 \\
\hline & 2018 & 0.47 & 15.24 & 32.45 & 10.02 & 36.02 & 26.76 \\
\hline & 2019 & 0.41 & 29.35 & 71.51 & 12.71 & 54.39 & 44.71 \\
\hline
\end{tabular}

Summarizing the financial performance indicators shown in Table 2, the authors conclude that the most stable situation is for "Company 1" Ltd., for which the financial independence ratio reaches the recommended limit - 0.5 , as well as the other indicators improved in the analysis period, for example, the turnover of payables decreased to 133 days in 2019 and the return on assets (ROA) reached $5.9 \%$ and the return on equity increased to $11.28 \%$ in 
2019. For "Company 2" Ltd., changes in the financial independence ratio ranged from negative $(-0.10)$ to positive -0.71 in 2019 . During the analysis period, the best year for this company was 2018 .

The total balance sheet of "Company 3" Ltd. doubled in the reporting period, reaching the amount of EUR 746,137, which related to the increase in current assets and short-term liabilities. The company's financial system was stable and attractive to external creditors.

According to the authors, in order to assess the impact of quality management system costs and the extent of this impact on the financial performance of the companies, it is necessary to compare the ratio of the total annual cost of the quality management system to the balance sheet total (see Table 3).

Table 3. Ratios of the annual costs of the quality management system to the total balance sheet of the company for "Company 1" Ltd., “Company 2" Ltd. and “Company 3" Ltd., 2017-2019 (authors' construction based on the company's financial data (published and unpublished))

\begin{tabular}{|c|c|c|c|c|}
\cline { 2 - 5 } \multicolumn{1}{c|}{} & $\begin{array}{c}\text { Reporting } \\
\text { year }\end{array}$ & $\begin{array}{c}\text { Total certification } \\
\text { costs, EUR }\end{array}$ & $\begin{array}{c}\text { Balance sheet } \\
\text { total, EUR }\end{array}$ & Relation \\
\hline \multirow{3}{*}{$\begin{array}{c}\text { “company 1" } \\
\text { Ltd. }\end{array}$} & 2017 & 125500 & 11187876 & $1 \%$ \\
\cline { 2 - 5 } & 2018 & 172700 & 11784128 & $1 \%$ \\
\cline { 2 - 5 } & 2019 & 114400 & 11330996 & $1 \%$ \\
\hline \multirow{4}{*}{$\begin{array}{c}\text { Company 2" } \\
\text { Ltd. }\end{array}$} & 2017 & 176300 & 1271110 & $14 \%$ \\
\cline { 2 - 5 } & 2018 & 122250 & 1555892 & $8 \%$ \\
\cline { 2 - 5 } & 2019 & 98600 & 2094034 & $5 \%$ \\
\hline \multirow{2}{*}{\begin{tabular}{c} 
Ltd. \\
\cline { 2 - 5 }
\end{tabular}} & 2017 & 78000 & 345829 & $23 \%$ \\
\cline { 2 - 5 } & 2018 & 72700 & 398965 & $18 \%$ \\
\hline
\end{tabular}

From Table 3, the authors concluded that the costs of the quality management system as a percentage of the balance sheet total are low, for example, in 2019 for "Company 1" Ltd., the costs of the quality management system accounted for $1 \%$ of the balance sheet total, $5 \%$ for "Company 2 " Ltd. and $11 \%$ for "Company 3 " Ltd. This confirms that the quality management system has many advantages, but it does not bring any financial benefits to the company, nor does it incur disproportionate costs.

The advantages of the quality management system of the companies and their interaction with the financial performance of the companies are shown in Table 4. 
Table 4. Impacts* of the quality management system standard ISO 9001 on the financial performance of companies (authors' construction based on the authors' experience and financial analysis)

\begin{tabular}{|l|c|c|c|}
\hline & $\begin{array}{c}\text { “Company 1" } \\
\text { Ltd. }\end{array}$ & $\begin{array}{c}\text { “Company 2" } \\
\text { Ltd. }\end{array}$ & $\begin{array}{c}\text { “company 3" } \\
\text { Ltd. }\end{array}$ \\
\hline IS0 9001 standard maintenance costs & negative & negative & negative \\
\hline $\begin{array}{l}\text { Quality department maintenance } \\
\text { costs }\end{array}$ & negative & negative & negative \\
\hline $\begin{array}{l}\text { The possession of the ISO 9001 } \\
\text { certificate helps to streamline the } \\
\text { company's processes }\end{array}$ & neutral & positive & negative \\
\hline $\begin{array}{l}\text { The existence of the ISO 9001 } \\
\text { standard helps to gain customers }\end{array}$ & positive & positive & positive \\
\hline $\begin{array}{l}\text { The possession of the ISO 9001 } \\
\text { certificate serves as a criterion in } \\
\text { procurement }\end{array}$ & positive & positive & $\begin{array}{c}\text { not } \\
\text { applicable }\end{array}$ \\
\hline $\begin{array}{l}\text { Improves business performance, } \\
\text { manages company risks }\end{array}$ & neutral & neutral & neutral \\
\hline Increases customer satisfaction & positive & positive & positive \\
\hline Investment attraction & positive & positive & positive \\
\hline
\end{tabular}

* Impact assessment:

Positive - the criterion promotes turnover growth or profit;

Neutral - the criterion does not affect / generate neither revenue nor expenditure;

Negative - indicates a situation where the criterion creates costs for the company;

Not applicable - the criterion is not applicable to the specific company.

Based on Table 4, it can be concluded that although several criteria have a positive impact on the financial performance of companies, for example, customer attraction and satisfaction increase turnover. However, the financial benefits it provides cannot be unequivocally determined. Improving and streamlining processes can also make a positive financial contribution if the work is done more efficiently and consumes less resources, but it can also make a negative contribution if these processes are carried out in a hurry.

The research confirms that changes in the financial performance of the companies are not affected by the presence or absence of a quality management system. According to the research data, all the three companies are improving their financial situations for higher profits and business development. In 2020, two companies attracted additional financing, which is also necessary for "Company 3" Ltd.

In order to better assess the impacts of the quality management system on the financial performance of the companies, further independent research is needed to take into account the interaction of the quality management system with the financial performance of the companies in the future 
development of the companies - what financial benefits / losses provide particular process improvements.

\section{Conclusions and Proposals}

\section{Conclusions}

The concept of quality has become much broader in the 21st century, so it is increasingly important to base the quality management system of a company on a combination of the latest theories and practices of the industry. The current ISO 9001 quality standard does not provide specific guidelines for setting up a quality management system, its requirements are very general and vague to be adaptable to all types of companies, both in terms of their size and the type of product or service sold.

Evaluating the ISO 9001 standard, it can be concluded that the advantages outweigh the disadvantages, as a company that is willing to invest time and resources in setting up an ISO 9001 quality management system benefits from three reasons: streamlined and established transparent business processes; optimized company processes and increased company profit; the company's operating principles for customers and cooperation partners are approved by an accredited certification body, which regularly conducts audits of the company, checking its compliance and directing the company's customer-oriented process management.

Based on the analysis of the costs of the companies' quality management systems directly related to the maintenance of the ISO 9001 certificate, it can be concluded that the situation is similar in all the three companies: 80-97\% are specialist wages, the other related costs (certification costs, training, department, measuring instruments) make up only 1-5\%. In total, the highest quality system costs were found for "Company 1" Ltd., on average in the research period it was EUR 137 533, similar costs were also found for “Company 2" Ltd. at EUR 132 383, while "Company 3" Ltd had the lowest costs at EUR 78416.

Comparing the ratio of the total annual cost of the quality management system to the balance sheet total reveals that the costs of the quality management system as a percentage of the balance sheet total are low, for example, in 2019 for "Company 1" Ltd., the costs of the quality management system accounted for $1 \%$ of the balance sheet total, $5 \%$ for "Company 2 " Ltd. and $11 \%$ for "Company 3 " Ltd. This confirms that the quality management system has many advantages, but it does not bring any financial benefits to the company, nor does it incur disproportionate costs.

All the three companies surveyed are taking steps to improve their financial situation in order to make more profits and develop their businesses. The financial position of the companies is not affected by the existence of a quality management system in the companies, i.e. not having a 
quality management system, the financial performance would be almost constant, as a quality management system is a way of managing a company and organizing processes that is developed and maintained throughout the company. Consequently, a quality management system has many advantages, but it does not provide a specific financial benefit to the company, nor does it entail disproportionate costs.

Based on the analysis of the research data, the hypothesis put forward was partially confirmed. The costs and financial benefits of the quality management system are too small to affect the company's financial situation; however, the quality management system helps to streamline the company's internal processes and indicates the high level of the company's quality to customers.

\section{Proposals}

The costs of the quality management system should include the amounts of products and services for which complaints or complaints have been received and the costs of remedying them, as well as the costs of production and reproduction incurred during the production process.

To increase the quality, "Company 1" Ltd. would need to:

- improve the equipment of the Laboratory, to arrange the reference instruments for verification and calibration of measuring instruments;

- increase interdepartmental cooperation in improving processes; especially between the warehousing and accounting departments;

- review and rethink the system of employee wages and motivations, because the company has a high turnover of employees;

- involve more employees in the development of new products;

- create and use customer satisfaction questionnaires on a daily basis.

The authors propose to increase the quality of "Company 2" Ltd. through:

- improving descriptions of internal processes, changing the format of descriptions;

- defining more precisely job responsibilities for employees, as well as introducing the employees to the positions of other employees and their responsibilities.

"Company 3" Ltd. needs to increase quality through:

- finding the necessary resources and certifying the company in accordance with the ISO 9001 standard;

- involving employees working on new product development;

- creating and using customer satisfaction questionnaires on a daily basis. 
In order to better assess the impacts of the quality management system on the company's financial performance, further independent research would be needed, which would take into account the interaction of the quality management system with the company's financial performance.

\section{References}

1. Başaran, B. (2016). The effect of ISO quality management system standards on industrial property rights in Turkey. World Patent Information, 45, pp. 33-46.

2. Driṇke, Z. (2019). Kvalitātes vadības sistēmas Latvijas mazo un vidējo uzñēmumu konkurētspējas paaugstināšanai. Rīga: Biznesa augstskola "Turība”.

3. Forands, I. (2009). Biznesa vadības tehnoloǵijas. Rīga: Latvijas Izglītības fonds.

4. Handke, D., Edelhoff, D. (2016). Quality and risk management strategy for mechanized tunnelling - From machine concept to process controlling. Geomechanics and Tunnelling, 9 (3), 222-233.

5. ISO 9001. (S.a.). Hyderabad: SPK Global Solutions. Retrieved from http://spkglobalsolutions.com/iso-9001/, sk. 25.12.2019.

6. ISO Survey of certifications to management system standards: ISO 9001 - data per country and sector, 1993 to 2017. (2020). OpenText Content Server, 1995-2020. Retrieved

from

https://isotc.iso.org/livelink/livelink?func=ll\&objId=21413346\&objAction=brows e\&viewType $=1$

7. Kravchenko, T., Saienko, I. (2020). World Experience Of Process Quality Management Of Teacher Training In Hei. Baltic Journal of Economic Studies, 6(4), 90-97.

8. Kvalitātes pārvaldības sistēmas. Prasības (ISO 9001:2015). (2017). Rīga: Latvijas standarts.

9. Kvalitātes vadīšana. (1999). Rīga: Kamene.

10. Meža nozare cilvēkam. (B. g.). Rīga: Zaḷās mājas. Retrieved from: https://site335431.mozfiles.com/files/335431/meza nozare cilvekam web copy.pdf?147860 $\underline{9918}$

11. Meža nozare skaițlos un faktos: 2018. (2019). Rīga: Zaḷās mājas, 54 lpp. Retrieved from: https://www.zm.gov.lv/public/ck/files/skaitlifakti LV 2018web.pdf, sk

12. Meža nozare skaiț̣os un faktos: 2021. (2020). Rīga: Zaḷās mājas, 52 lpp. Retrieved from:

https://www.zm.gov.lv/public/ck/files/ZM/mezhi/buklets/skaitlifakti LV 2021.pdf

13. SIA “Uzṇēmums 3" mājaslapa. (2020). Tiešsaistes resurss, sk. 27.04.2020.

14. SIA “Uzñemums 3" pamatdati. (2020). Rīga: Lursoft. Tiešsaistes resurss, sk. 28.04.2020.

15. Байда, Е.А. (2016). Система экономики качества как инструмент оценки экономической эффективности организации. Концепт, научно-методический электронный журнал, 4, с. 2.

\section{Unpublished materials:}

1. Intervija ar SIA “Uzñēmums 1" izpilddirektoru S. K. (2020).

2. SIA "Uzṇēmums 1" bilance, 2017-2019. (Iekšējie dokumenti / nepublicētie materiāli)

3. SIA "Uzṇēmums 1" iekšêjie dokumenti (nepublicētie materiāli).

4. SIA “Uzñèmums 1" Pelñas/zaudējumu aprēk,ins, 2017-2019. (Iekšējie dokumenti / nepublicētie materiāli)

5. SIA “Uzṇēmums 2" bilance, 2017-2019. (Iekšèjie dokumenti / nepublicētie materiāli) 
6. SIA "Uzṇēmums 2" iekšèjie dokumenti (nepublicētie materiāli).

7. SIA “Uzñēmums 2" Peln,nas/zaudējumu aprēḳins, 2017-2019. (Iekšējie dokumenti / nepublicētie materiāli)

8. SIA “Uzṇēmums 3" bilance, 2017-2019. (Iekšējie dokumenti / nepublicētie materiāli)

9. SIA “Uzñēmums 3" iekšējie dokumenti (nepublicētie materiāli).

10. SIA “Uzñēmums 3" Peln,nas/zaudējumu aprēk,ins, 2017-2019. (Iekšējie dokumenti / nepublicētie materiāli) 